\title{
In search of optimal psychoactivation: stimulants as cognitive performance enhancers
}

\author{
Emil Bartosz Rozenek ${ }^{1}$, Monika Górska², Karolina Wilczyńska ${ }^{3}$, and Napoleon Waszkiewicz ${ }^{3}$ \\ ${ }^{1}$ Medical University of Bialystok, Bialystok, Poland \\ ${ }^{2}$ Medical University of Lodz, Lodz, Poland \\ ${ }^{3}$ Department of Psychiatry, Medical University of Bialystok, Choroszcz, Poland
}

[Received in May 2019; Similarity Check in May 2019; Accepted in August 2019]

\begin{abstract}
An increasing number of people, students in particular, seek substances that improve their cognitive functioning. The most popular group of pharmacological cognitive enhancers (PCEs) are stimulants. Available studies suggest a small beneficial effect of methylphenidate and amphetamine on memory, executive functions, and processing speed. However small, this effect can make the difference between success and failure. In recent years, research has focused on the additional beneficial effect on the emotional state, increased motivation, and placebo-induced cognitive enhancement. This paper briefly reviews the latest and most important research on the relationship between popular stimulants and cognitive enhancement. One cannot understand this relationship without understanding the Yerkes-Dodson law, which explains the relationship between the degree of arousal and performance. It suggests that the effect of stimulants is a dose-dependent continuum. This law has repeatedly been confirmed by studies in which an optimal level of psychoactivation for cognitive enhancement was obtained with low stimulant doses, whereas exceeding the effective dose resulted in cognitive deficits, psychomotor agitation, and addiction. A separate section has been devoted to modafinil, an increasingly popular stimulant that differs from the rest in neurochemical profile and behavioural effects.
\end{abstract}

KEY WORDS: amphetamine; central nervous system stimulants; cognition; methylphenidate; modafinil

An increasing number of students and employees use substances considered to be cognitive performance enhancers to improve their academic and/or professional results. The most common group of substances used for these reasons are stimulants such as amphetamine. In many countries these substances are legal and registered for the treatment of various disorders. However, even when clinically indicated, they raise much doubt and apprehension because of their addictive potential. This review summarises the latest and most important information on the epidemiology, efficacy, and mechanisms of action of stimulants used for cognitive enhancement. It further explores the relationship between stimulant dose and cognitive performance based on the Yerkes-Dodson law.

The concept of cognitive enhancement refers to the multifaceted improvement of human cognitive abilities in a healthy population. There are various methods to achieve it, including pharmacological, biotechnological, and those involving information technology (1-3). In ancient civilizations, pro-cognitive substances such as hallucinogens were supposed to facilitate contact with deities (4). Today, pharmacological cognitive enhancement is one of the most commonly discussed topics in the neuroscience community $(4,5)$. Some scientists consider the use of pharmacological

Corresponding author: Emil Bartosz Rozenek, Medical University of Bialystok, Bialystok, Poland, E-mail: e.rozenek@o2.pl substances away of fulfilling the eternal human desire for self-improvement (6).

\section{LITERATURE SEARCH}

This review is based on MEDLINE database search using English key terms related to pharmacological cognitive enhancement and the use of the most common stimulants for this purpose, namely amphetamine, methylphenidate, and modafinil. We excluded other stimulants, non-stimulant cognitive enhancers (e.g. racetams and vinpocetine) or drugs used by patients with Alzheimer's disease or Parkinson's disease with dementia (e.g. acetylcholinesterase inhibitors like donepezil and rivastigmine or NMDA receptor agonists like memantine) to improve cognitive functions impaired by their neurodegenerative disorders.

We used the following query: cognitive enhanc*[Title/ Abstract] AND (amphetamine [Title/Abstract] OR methylphenidate*[Title/Abstract] OR modafinil [Title/ Abstract]) and set the publication date range from 1 January 2000 to 2 May 2019. The resulting 228 hits, in our opinion, did not reflect all the important publications on the subject matter. For this reason, we repeated the search with each of the above-mentioned key words alone. The resulting hits added the latest publications, some of which explained the 
pharmacological mechanisms of these substances. This review includes 90 key publications, the majority of which are review articles (including current systematic reviews and meta-analyses) and original research articles, but due to the popularity of the subject, we also included chapters from books, internet publications, and press reports.

In order to make the content of the review more understandable, we also included basic information about the Yerkes-Dodson law, based mainly on the original results of the authors' experiment.

\section{DEFINITION AND EPIDEMIOLOGY OF PCE}

Pharmacological cognitive enhancement (PCE) is defined as an increase in cognitive functions - memory, attention, creativity, and intelligence (understood as a problem-solving skill) in particular - in healthy individuals with the help of prescription drugs not medically indicated for this purpose $(3,4)$. This is well illustrated by population studies involving college students - a group predisposed to use PCEs and thus the most thoroughly studied in terms of PCE use (7-11).

The most common pharmacological cognitive enhancers (PCEs) are stimulants used in the treatment of attention deficit hyperactivity disorder (ADHD), and/or narcolepsy. and include amphetamine salts, methylphenidate, and modafinil $(7,12-15)$.

Methylphenidate and amphetamine salts (or simply amphetamine) are most commonly used in the USA for ADHD (16). In 2016, $5.1 \%$ of all US children between 2 and 17 years was taking some form of ADHD medication (17), whereby researchers estimate that as many as $30 \%$ (11.4 million) of prescriptions intended for children with ADHD are used outside their indication $(18,19)$. Articles about cases of prescription extortion by parents are easy to encounter in the press. These cases fall into two categories: parents want their child to perform as well as their peers at school "my child must be on methylphenidate, because all the others are taking it!" (20) or a drug prescribed for a child is actually used as a stimulant by the parent $(21,22)$.

In turn, $4.4 \%$ of US adults aged 18 to 44 years suffer from ADHD (23), but misuse of stimulants has been reported in adults with and without $\operatorname{ADHD}(24,25)$.

In a 2008 systematic review Wilens et al. (24) established that 16-29\% of students prescribed with stimulants were at least once asked to give, sell, or trade their medication. Similarly, Poulin (26) reported that $26 \%$ of the surveyed students prescribed with stimulants admitted to have given or sold some of their medication to their peers in the past month. As this diversion often occurs between peers at school or college - an environment where students seek to achieve success - the issue may seem less serious than drug abuse found in more marginalised environments (18). In any case, as many as $10 \%$ of youth aged $12-25$ years who have abused stimulants in the past year may meet the criteria for substance dependence (27).

A drug that is becoming increasingly available as a "lifestyle drug" improving performance in healthy individuals is modafinil. In addition to its indicated use to treat narcolepsy-related sleepiness, it is legally distributed among healthy American, British, French, and Indian soldiers, as it helps them remain awake after a sleepless night, which is particularly useful in military conditions. In the US it has replaced amphetamine, previously used for this purpose $(28,29)$. However, it is also often sold illegally online (30).

Whether we like it or not, stimulants are used legally and illegally, which raises the issue of broadening legal use of stimulants. Proponents of legalisation point out that

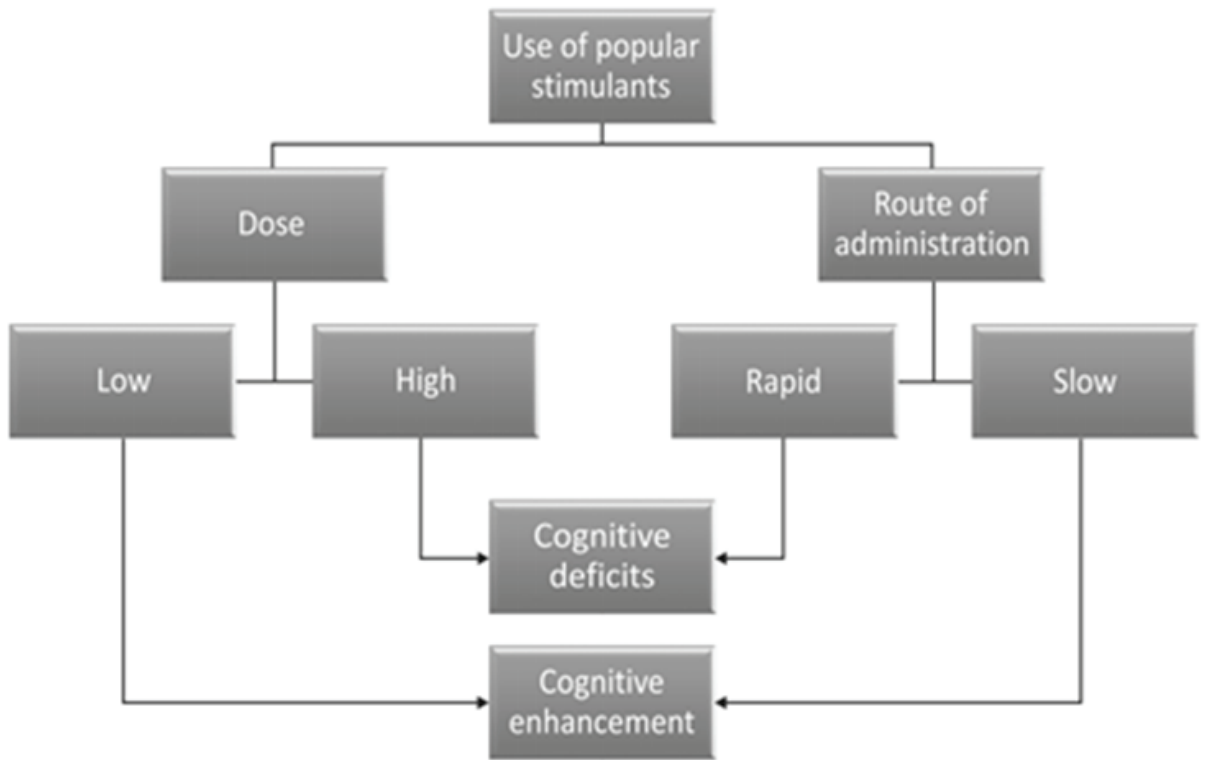

Figure 1 Stimulant dose- and route-dependent cognitive performance [based on a review by Wood et al. (49)] 
professions such as a doctors, surgeons, or judges could benefit from a reasonable use of stimulants (see the YerkesDodson law below) and so could the society $(8,29)$.

\section{THE USE OF PCEs AMONG STUDENTS OF MEDICINE AND OTHER PROFESSIONS}

Nowadays, healthy students at universities around the world often acquire prescription stimulants not to get intoxicated ("get high") - as can be the case with amphetamine or methylphenidate (known in street slang as the poor man's cocaine) $(31)$ - but to improve their academic performance $(18,29)$. This phenomenon is considered a growing global trend (18). Medical students constitute a special group, because of the amount of material they are required to absorb, and in many countries academic performance is a decisive factor in the choice of internship and specialisation. The duration of their studies is longer than in other fields, which makes it difficult to earn a living on the side. This puts them at risk of using legal and illegal substances in order to improve their academic performance and cope with stress.

One would expect that medical students use stimulants more often than other students, as suggested by some recent reports $(8,32)$, but this may be misleading, as they compare their results with a decade older study by McCabe et al. (33) on a large sample of students of various professions, who may not have been as well acquainted with stimulants as they are now. In the meanwhile, stimulants have become more popular and better studied. This raises a need to compare the current frequency of stimulant use by students of medical universities and other universities.

In 2011, Emanuel et al. (34) conducted an internet survey that included over 1,000 medical students in Chicago. Eleven percent of respondents admitted using non-prescription stimulants during studies. A 2010 study with nearly 400 US medical students (35) reported a similar percentage (10.1\%) of misuse. Webb et al. (36) reported a higher percentage $(15 \%)$ but in a relatively small sample of 144 medical students. Nine percent of respondents, however, had a confirmed diagnosis of ADHD, which is almost twice as high as in the general adult population of adults (23). Eighty-three percent of the respondents using stimulants reported that they did it to enhance their cognitive performance or to stay awake longer while on clinical duties.

The 2004 McCabe et al. study (33) reported that $6.9 \%$ of nearly eleven thousand college students at various US universities admitted having misused stimulants at least once in their lifetime. Using multivariate regression analysis, they found that non-medical use was the most common among white male college students who were members of fraternities and sororities, and had lower grade point averages. In 2008, Wilens et al. (24) published a systematic review of 21 studies with 213,104 participants regarding the misuse and diversion of stimulants prescribed for ADHD. The rate of non-medical use in the past year ranged from $5 \%$ to $9 \%$ in grade-school and high-school children and from $5 \%$ to $35 \%$ in college students. These $35 \%$ were, in fact, reported by Low and Gendaszek (37) among the 150 participating students of undergraduate psychology classes, $80 \%$ of whom misused ADHD prescription drugs to enhance their performance at school. These findings are comparable to those reported by Webb et al. (36) for a similar sample of medical students. In the Barrett et al. study (38), which was also included in the systematic review by Wilens et al. (24), $70 \%$ of respondents misused stimulants recreationally, whereas $30 \%$ did it in order to study more effectively. Teter et al. (39) conducted an internet survey among 4580 college students. It turned out that the most commonly reported motives for stimulant misuse were to improve concentration $(65.2 \%)$, facilitate studying $(59.8 \%)$, and increase alertness $(47.5 \%)$. Other motives included getting high (31.0\%) and experimenting (29.9 \%). Another web-based study (40) among 2,877 German university students from randomly selected disciplines reported high cognitive anxiety about the consequences of failing, low intrinsic motivation, low internalisation of social norms against cognitive enhancers, and positive past experiences as motives for misuse.

\section{SCIENTIFIC EVIDENCE OF EFFICIENT COGNITIVE ENHANCEMENT BY STIMULANTS}

Substances used in the treatment of ADHD at clinically relevant doses improve cognitive functioning associated with frontostriatal pathways in ADHD patients and healthy individuals (16). In 2014, Bagot and Kaminer (18) published a systematic review of data collected from 14 randomised, double-blind, placebo controlled trials on the effectiveness of stimulants (methylphenidate, amphetamine, and modafinil) in enhancing cognitive function in healthy youth (12-25 years) without ADHD diagnosis. Methylphenidate appeared to significantly improve performance in novel tasks and attention-based tasks $(P \leq 0.05)$, while reducing planning latency in more complex tasks $(\mathrm{P} \leq 0.05)$. The review also showed that amphetamine significantly improved memory consolidation $(\mathrm{P} \leq 0.05)$, which led to improved recall, whereas modafinil, whose mechanism of action differs from typical stimulants (see below) appeared to improve reaction time $(\mathrm{P} \leq 0.04)$, logical reasoning $(\mathrm{P} \leq 0.05)$, and problem-solving.

In 2015, Ilieva et al. (41) published a meta-analysis of 48 double-blind, placebo-controlled trials with a total of 1,409 participants - all healthy young and middle-aged individuals - showing that the effects of amphetamine and methylphenidate on cognitive functions crucial for academic and occupational functioning were rather small but significant for inhibitory control (inhibiting dominant 
behaviour for the sake of achieving the goal) (Hedges' $\mathrm{g}=0.20)$, working memory $(\mathrm{g}=0.13)$, and short-term episodic memory tested up to 30 minutes after learning $(\mathrm{g}=0.20)$. A moderate effect size $(\mathrm{g}=0.45)$ was found only in delayed episodic memory, tested one hour to one week after learning. As the authors conclude, these results suggest that memory consolidation is affected by stimulants to a greater degree than memory encoding or retrieval. This conclusion confirms earlier reports (42-44).

Ilieva et al. (41) also speculated that amphetamine and modafinil might improve other learning-adjacent domains of cognition such as processing speed. This speculation was later confirmed in a systematic meta-analysis by Marracini et al. (45) based on double-blind placebo-controlled trials, which showed that prescription stimulants positively influenced processing speed in healthy adults (overall mean size effect of $\mathrm{g}=0.282$ ). Planning time, planning accuracy, cognitive perseveration, or advantageous decision-making were neither improved nor impaired, although these outcomes were investigated only in a small number of studies.

Taking into consideration their previous work, Ilieva et al. $(41,46)$ do not exclude the possibility that the benefits of PCEs in healthy individuals are partly owed to elevated mood and motivation and not only to their effects on cognitive function. In fact, they suggest that while individuals with depression or undiagnosed ADHD may benefit from stimulants, those with anxiety or bipolar disorder may suffer adverse effects due to excessive arousal. They admit, however, that only future, properly designed studies should be able to confirm this hypothesis. Theirs and other studies show that stimulants might alter emotional approach to a task, so that individuals who ingested a stimulant experience more satisfaction and change their perception of the task from unattractive to attractive (46, 47). Interestingly, a placebo-controlled study from 2017 (48) suggested that stimulant-induced cognitive enhancement might in fact largely depend on individual expectations rather than purely pharmacologic action (placebo-induced cognitive enhancement).

\section{PCE-INDUCED COGNITIVE ENHANCEMENT OR DECLINE IS DOSE- DEPENDENT}

The use of stimulants, even in the case of ADHD treatment, raises certain concerns in the society. This is understandable, because the term stimulants is also associated with the negative consequences of psychoactivation such as addiction, excessive psychomotor agitation, and aggressive behaviour $(16,29)$. However, when it comes to ADHD treatment or cognitive enhancement, such concerns have not yet been scientifically founded.

In a 2014 review Wood et al. (49) focused on animal studies, including their own, examining the relationship between stimulant dose and psychoactivation, including an increase or decrease in cognitive function. At low, clinically relevant doses of stimulants administered orally they observed cognitive enhancement accompanied with a slight, beneficial increase in arousal and motor activation (see also the Yerkes-Dodson law below). Higher doses and/or rapid routes of administration (e.g. injections) resulted in adverse hyperlocomotion and euphoria (the latter being closely related to addiction). Still higher psychoactivation impaired cognitive function. Further dose increase was associated with the symptoms of overdose, such as agitation, confusion, and psychosis, and eventually circulatory failure and death. This, in terms of stimulants, is called a continuum of psychoactivation (49). According to Spencer et al. (16), low stimulant doses selectively increase the concentration of catecholamines in the pre-frontal cortex, which, in turn, act on norepinephrine $\alpha 2$ and dopamine D1 receptors and enhance cognitive function. They also point to a stark contrast between the regionally selective action of low stimulant doses and the non-selective effects of higher doses. Research and imaging studies have shown the prefrontal cortex is critically involved in memory tasks (5052 ), guiding behaviour during divided attention (53), and planning (54).

\section{THE RELATIONSHIP BETWEEN AROUSAL AND PERFORMANCE}

\section{The Yerkes-Dodson law}

One of the oldest proposals regarding the relationship between the degree of arousal and the level of task-oriented functioning (e.g. learning speed) is based on the research of Robert Yerkes and John Dodson. In 1908, the two published the results of a study that examined the influence of strength of electrical stimuli on the speed at which mice learned how to distinguish fields with different intensity of illumination. With a simpler task, which was to avoid fields with clearly stronger light intensity, the learning time decreased linearly with the increase of the stimulus. With a more difficult task (to distinguish two fields with similar light intensity), the learning curve assumed the shape of an inverted "U", as learning was the quickest with moderate stimulus, achieving the optimal level of arousal (Figure 2) (55).

Further research by Yerkes (56) and Dodson (57) confirmed these findings. In the years that followed, other authors (58-60) replicated these experiments using more modern research methods for measurement and statistical analysis. In 1957, Broadhurst (59) reported a noticeable decrease in rat performance when faced with a difficult task at high level of body stress. With easy tasks, in contrast, the highest stress level had the best influence on performance. In 2010, Salehi et al. (60) confirmed the inverted U-shape 
function of memory and stress intensity in rats performing a hippocampus-dependent learning task.

Yerkes's and Dodson's experiments lay the foundation for the Yerkes-Dodson law, which says that a high level of arousal can improve performance with easy tasks or worsen it with difficult tasks. According to Diamond et al. (61), learning how to perform easy task is a simple learning condition that involves focused attention to an isolated cue with minimal cognitive (decision-making) demands. More complex or challenging learning conditions are associated with performing a difficult task demanding divided attention and/or strongly involving working memory.

Some researchers explain low tolerance of arousal in difficult tasks with the reticular formation triggering mechanisms that prevent the awareness of all incoming information or simplifying it. Without this regulation, the body would be unable to cope with the complexity of reality reaching awareness. This would lead to disorganisation of its response (62).

According to more recent studies summarised by Lafreniere in an introduction to the reversal theory in psychology (63), the impact of arousal on functioning may also depend on the meta-motivational status of the individual towards the surrounding reality. Taking into account the Yerkes-Dodson law, in the telic state (also known as "serious" state), where subjects are focused on achieving a specific goal, they should avoid excessive stimulation, as it would generate negative emotions (e.g. anxiety) and decrease performance. In the paratelic (or playful) state, in turn, when the focus is on the activity instead of the goal, additional stimulation may increase efficacy.

In addition to situational conditions, personality factors are also important. It has been proven that people differ in their persistent attitude to functioning in the telic or paratelic state, which largely determines the differences in the efficiency of their functioning in certain states of emotional arousal $(63,64)$. Salehi et al. (60) not only confirmed the Yerkes-Dodson law but also evidenced individual differences in rat performance at either high or low stress conditions. They suggest that personality types may differ in their cognitive performance when exposed to stress, but this hypothesis needs to be tested in human studies.

In terms of stimulants, these concerns are justified, because healthy individuals may not have a purely cognitive benefit from PCEs. Instead, it may at least partly result from motivation, higher energy levels, and influence on affective states $(41,46)$.

Nowadays, the conclusions drawn from Yerkes-Dodson studies (55-58) are widely applied in many areas, including athletic training, computer gaming, and workplace design (58).

\section{MODAFINIL: NOT A TYPICAL STIMULANT}

Amphetamine and methylphenidate block norepinephrine and dopamine reuptake, which, in turn, strongly increases their extracellular levels. Amphetamine also stimulates dopamine efflux through an action believed to involve the entry of the drug into dopamine terminals and a reversal in the operation of the dopamine reuptake transporter. Amphetamine can also stimulate norepinephrine efflux and block serotonin reuptake, though this only occurs at quite high and clinically inappropriate doses (16). In contrast to amphetamine, methylphenidate neither inhibits serotonin reuptake nor stimulates norepinephrine or dopamine efflux (65). In line with the continuum of psychoactivation, at low doses amphetamine and methylphenidate preferentially target the pre-frontal cortex $(16,66)$, which is responsible for cognitive enhancement, whereas at higher doses their action is not preferential and affects subcortical areas as well, resulting in motor activation and arousal $(16,67,68)$.

Modafinil, in turn, affects several neurotransmitter pathways, including dopamine and norepinephrine (69), 5-HT (70), GABA (71), glutamate (72) and histamine,
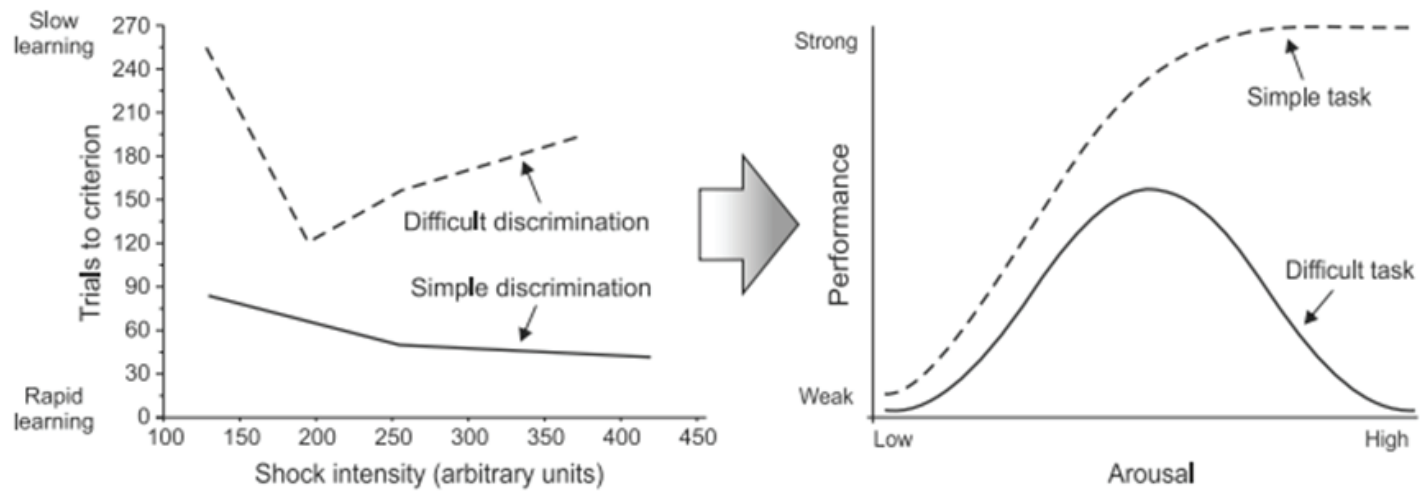

Figure 2 A subset of data from Yerkes and Dodson (55) (left) presented in the form of a graph by Diamond et al. (61) (right) showing the relationship between arousal and performance of simple and complex tasks. The smaller the number of trials to criterion, the faster the mice learned. The optimal level of mice arousal (electric shock stimulation) was recorded only when the difficult task was performed 
which some studies reported to be orexin-mediate (73), though its mechanism of action has yet to be discovered. Because of its wake-promoting properties, it has been regarded as a stimulant, but several animal and human studies suggest that its mechanism of action differs from that of classic stimulants. Its primary therapeutic mechanism appears to be dopamine reuptake via dopamine transporter, some of its stimulant profile may be owed to nondopaminergic mechanisms (74).

In 2010, Repantis et al. (3) published a meta-analysis of 31 single- or double-blind randomised or quasirandomised controlled clinical trials, including cross-over clinical trials, which compared modafinil with placebo in healthy individuals. Single-dose modafinil had moderate enhancing effects on attention in non-sleep-deprived, wellrested individuals compared to a placebo, but no statistical difference was found for memory, mood, or motivation. In sleep-deprived individuals single-dose modafinil significantly enhanced wakefulness, executive functions, and memory without effects on mood. Repeated intake of modafinil during sustained sleep deprivation over several days maintained higher wakefulness than placebo, and this effect lasted for up to four days. However, attention and executive functions were not sustained with repeated doses. Repeated administration of modafinil to well-rested individuals was reported by only two studies, whose combined samples were not sufficient for statistical analysis.

A few years later, Battleday and Brem (2) published a systematic review of 24 randomised, double-blind, placebocontrolled prospective studies, all performed on healthy, non-sleep-deprived subjects. In simple tasks, modafinil improved executive function, variably enhanced attention, learning, and memory, but did not affect creativity and motor excitability. In complex tasks it enhanced attention, executive function, learning, and memory. Negative cognitive effects were reported occasionally and never consistently for any of the functions. Positive effects on mood were minimal, but Repantis et al. (75) commented in a letter to the editor that Battleday et. al failed to provide a definition of mood.

As for sleep-deprived healthy patients, Wesensten et al. (76) examined their alertness and performance after taking modafinil in therapeutic doses (200 or $400 \mathrm{mg}$ ) compared to caffeine use $(600 \mathrm{mg})$. Wakefulness and performance improved in respect to placebo controls and corresponded to results achieved with caffeine. This was later confirmed by another study of the same authors (77) in healthy, sleepdeprived patients who received $400 \mathrm{mg}$ of modafinil or $600 \mathrm{mg}$ of caffeine. Both substances improved psychomotor vigilance speed and objectively measured alertness compared to a placebo. A similar enhancement was also observed for some aspects of the executive function (e.g. improved learning on the Wisconsin Card Sorting Test and better performance on the Biber Cognitive Estimation Test).

Modafinil also appears to improve decision-making, as evidenced by Franke et al. (78), who had their subjects play chess against a computer program. These improvements, however, were evident only when the subjects were not under the pressure of time.

Modafinil has a low abuse potential (79) and at therapeutic doses does not produce euphoria in either substance abusers (80) or healthy subjects (81). A recent study (82) has showed that doses low enough not to cause hyperarousal (200 $\mathrm{mg}$ and $400 \mathrm{mg}$ ) were enough to achieve domain-specific attention enhancement in healthy, nonsleep-deprived participants. However, rare cases of modafinil dependence do exist $(83,84)$. While still enhancing cognitive function in healthy people, a single dose of $600 \mathrm{mg}$ increased neural activation in the brain regions linked to fear processing (85). Due to its unique psychostimulatory profile, modafinil could be useful in the treatment of cocaine (86) and methamphetamine (87) addiction. Furthermore, it might improve cognition in methamphetamine-dependent individuals, as suggested by Ghahremani et al. (88).

\section{CONCLUSION}

Latest research indicates that stimulant-assisted performance enhancement is not owed to the beneficial effects on cognitive functioning alone but also to improved motivation and mood. In fact, some of the pro-cognitive effects may be owed to placebo.

What is important to note is that low and clinically indicated doses administered orally are not associated with adverse reactions typical of this group of drugs. Instead, psychoactivation is moderate, which favours cognitive enhancement. Psychoactivation is desirable for maximising our cognitive abilities, and we have learned so far that its optimal level depends on the difficulty of the task performed, personality, and current metamotivational state. This review, we hope, has successfully pointed out the beneficial effects of optimal psychoactivation per se. It does not necessarily need to stem from stimulant use, and we believe that better understanding of psychoactivation can improve work, education, and many other areas of life.

Another important finding we would like to point out is that stimulation may help with the performance of simple tasks (with a small number of cues requiring focus) but is rather counterproductive in complex and challenging tasks that engage more working memory. According to the reversal theory, it is important to realise whether satisfaction derives from performing a task (additional stimulation is beneficial) or from completing it (additional stimulation should be limited).

Stimulant use might be associated with reduced need to sleep. While such an effect could seem desirable if we were to assume that sleeping is a waste of time, even a short-term sleep disruption leads not only to depression and anxiety but also cause cognitive deficits $(89,90)$. Long-term sleep disruption, in turn, increases the risk of civilisation 
diseases and intensifies symptoms of many gastrointestinal conditions $(89,90)$. With all that in mind, uninformed use of stimulants could create a vicious circle (stimulants cause sleep disruption which produces cognitive deficits, which inclines us to use more stimulants). In contrast, practical use of knowledge on psychoactivation can improve our quality of life.

\section{REFERENCES}

1. Dubljević V, Venero C, Knafo S. What is cognitive enhancement? In: Knafo S, Venero C, editors. Cognitive Enhancement: Pharmacologic, Environmental and Genetic Factors. Amsterdam: Elsevier Inc.; 2015. p. 1-9. doi: 10.1016/ B978-0-12-417042-1.00001-2

2. Battleday RM, Brem A-K. Modafinil for cognitive neuroenhancement in healthy non-sleep-deprived subjects: A systematic review. Eur Neuropsychopharmacol 2015;25:1865-81. doi: 10.1016/j.euroneuro.2015.07.028

3. Repantis D, Schlattmann P, Laisney O, Heuser I. Modafinil and methylphenidate for neuroenhancement in healthy individuals: A systematic review. Pharmacol Res 2010;62:187206. doi: $10.1016 /$ j.phrs.2010.04.002

4. Frati P, Kyriakou C, Rio A, Marinelli E, Vergallo G, Zaami $\mathrm{S}$, Busardò FP. Smart drugs and synthetic androgens for cognitive and physical enhancement: revolving doors of cosmetic neurology. Curr Neuropharmacol 2015;13:5-11. doi: 10.2174/1570159X13666141210221750

5. Maslen H, Faulmüller N, Savulescu J. Pharmacological cognitive enhancement-how neuroscientific research could advance ethical debate. Front Syst Neurosci 2014;8:107. doi: 10.3389/fnsys.2014.00107

6. Farah MJ, Illes J, Cook-Deegan R, Gardner H, Kandel E, King P, Parens E, Sahakian B, Wolpe PR. Neurocognitive enhancement: what can we do and what should we do? Nat Rev Neurosci 2004;5:421-5. doi: 10.1038/nrn1390

7. Massie CF, Yamga EM, Boot BP. Neuroenhancement: a call for better evidence on safety and efficacy. In: ter Meulen R, Mohammed A, Hall W, editors. Rethinking Cognitive Enhancement. Oxford: Oxford University Press; 2017. p. $57-68$.

8. Lengvenyte A, Strumila R, Grikiniene J. Use of cognitive enhancers among medical students in Lithuania. Nord Stud Alcohol Drugs 2016;33:173-88. doi:10.1515/nsad-20160014.

9. Partridge BJ, Bell SK, Lucke JC, Yeates S, Hall WD. Smart drugs "as common as coffee": media hype about neuroenhancement. PLoS One 2011;6:e28416. doi: 10.1371/ journal.pone.0028416.

10. Benson K, Flory K, Humphreys KL, Lee SS. Misuse of stimulant medication among college students: A comprehensive review and meta-analysis. Clin Child Fam Psychol Rev 2015;18:50-76. doi: 10.1007/s10567-0140177-z

11. Nicholson PJ, Wilson N. Smart drugs: implications for general practice. Br J Gen Pract 2017;67:100-1. doi: 10.3399/ bjgp17X689437

12. Weyandt LL, Oster DR, Marraccini ME, Gudmundsdottir BG, Munro BA, Rathkey ES, McCallum A. Prescription stimulant medication misuse: Where are we and where do we go from here? Exp Clin Psychopharmacol 2016;24:40014. doi: $10.1037 /$ pha0000093

13. Sharbaf Shoar N, Marwaha R, Molla M. DextroamphetamineAmphetamine. Treasure Island (FL): StatPearls Publishing; 2019.

14. Verghese C, Abdijadid S. Methylphenidate. Treasure Island (FL): StatPearls Publishing; 2019.

15. Greenblatt K, Adams N. Modafinil. Treasure Island (FL): StatPearls Publishing; 2019.

16. Spencer RC, Devilbiss DM, Berridge CW. The cognitionenhancing effects of psychostimulants involve direct action in the prefrontal cortex. Biol Psychiatry 2015;77:940-50. doi: 10.1016/j.biopsych.2014.09.013

17. Danielson ML, Bitsko RH, Ghandour RM, Holbrook JR, Kogan MD, Blumberg SJ. Prevalence of parent-reported ADHD diagnosis and associated treatment among U.S. children and adolescents, 2016. J Clin Child Adolesc Psychol 2018;47:199-212. doi: 10.1080/15374416.2017.1417860

18. Bagot KS, Kaminer Y. Efficacy of stimulants for cognitive enhancement in non-attention deficit hyperactivity disorder youth: a systematic review. Addiction 2014;109:547-57. PMCID: PMC4471173

19. Swanson JM, Wigal TL, Volkow ND. Contrast of medical and nonmedical use of stimulant drugs, basis for the distinction, and risk of addiction: comment on Smith and Farah (2011). Psychol Bull 2011;137:742-8. doi: 10.1037/ a0024898

20. The Guardian. Boseley S, Lignel B. Generation meds: the US children who grow up on prescription drugs [displayed 24 March 2019]. Available at https://www.theguardian.com/ society/2015/nov/21/children-who-grow-up-on-prescriptiondrugs-us

21. NewsComAu. Shepherd T. Childrens'ADHD dexies turning parents into midnight runners. [displayed 24 March 2019]. Available at https://www.news.com.au/lifestyle/parenting/ childrens-adhd-dexies-turning-parents-into-midnightrunners/news-story/9346cfddc1bb1b6c11cf0feeefe $701 \mathrm{fc}$ ?sv $=7 \mathrm{c} 00 \mathrm{~d} 6 \mathrm{f} 8695 \mathrm{c} 1520561030 \mathrm{df5} 13 \mathrm{e} 3 \mathrm{f} 03$

22. HuffPost Life. Samakow J. Prescription Drug Abuse: Report Calls Parent Pill Popping An "Epidemic" [displayed 24 March 2019]. Available at https://www.huffpost.com/entry/ prescription-drug-abuse-parents_n_1515390

23. Kessler RC, Adler L, Barkley R, Biederman J, Conners CK, Demler O, Faraone SV, Greenhill LL, Howes MJ, Secnik K, Spencer T, Ustun TB, Walters EE, Zaslavsky AM. The prevalence and correlates of adult ADHD in the United States: results from the National Comorbidity Survey Replication. Am J Psychiatry 2006;163:716-23. doi: 10.1176/ ajp.2006.163.4.716

24. Wilens TE, Adler LA, Adams J, Sgambati S, Rotrosen J, Sawtelle R, Utzinger L, Fusillo S. Misuse and diversion of stimulants prescribed for ADHD: A systematic review of the literature. J Am Acad Child Adolesc Psychiatry 2008;47:2131. doi: 10.1097/chi.0b013e31815a56f1

25. Novak SP, Kroutil LA, Williams RL, Van Brunt DL. The nonmedical use of prescription ADHD medications: results from a national Internet panel. Subst Abuse Treat Prev Policy 2007;2:32. doi: 10.1186/1747-597X-2-32

26. Poulin C. From attention-deficit/hyperactivity disorder to medical stimulant use to the diversion of prescribed stimulants to non-medical stimulant use: connecting the dots. 
Addiction 2007;102:740-51. doi : 10.1111/j.1360-0443.2007.01758.x

27. Kroutil LA, Van Brunt DL, Herman-Stahl MA, Heller DC, Bray RM, Penne MA. Nonmedical use of prescription stimulants in the United States. Drug Alcohol Depend 2006;84:135-43. doi: 10.1016/j.drugalcdep.2005.12.011

28. South China Morning Post. Anonymous. PLA eyes "Night Eagle" to make army of night owls [displayed 25 March 2019]. Available at https://www.scmp.com/article/982075/ pla-eyes-night-eagle-make-army-night-owls

29. Greely H, Sahakian B, Harris J, Kessler RC, Gazzaniga M, Campbell P, Farah MJ. Towards responsible use of cognitiveenhancing drugs by the healthy. Nature 2008;456:702-5. doi: $10.1038 / 456702 a$

30. Kim D. Practical use and risk of modafinil, a novel waking drug. Environ Health Toxicol 2012;27:e2012007. doi: 10.5620/eht.2012.27.e2012007

31. Sussman S, Pentz MA, Spruijt-Metz D, Miller T. Misuse of "study drugs:" prevalence, consequences, and implications for policy. Subst Abuse Treat Prev Policy 2006;1:15. doi 10.1186/1747-597X-1-15

32. Kudlow PA, Treurnicht Naylor K, Xie B, McIntyre RS Cognitive enhancement in Canadian medical students. J Psychoactive Drugs 2013;45:360-5. doi: 10.1080/02791072.2013.825033

33. McCabe SE, Knight JR, Teter CJ, Wechsler H. Non-medical use of prescription stimulants among US college students: prevalence and correlates from a national survey. Addiction 2005;100:96-106. doi: 10.1111/j.1360-0443.2005.00944.x

34. Emanuel RM, Frellsen SL, Kashima KJ, Sanguino SM, Sierles FS, Lazarus CJ. Cognitive enhancement drug use among future physicians: findings from a multi-institutional census of medical students. J Gen Intern Med 2013;28:102834. doi: 10.1007/s11606-012-2249-4

35. Tuttle JP, Scheurich NE, Ranseen J. Prevalence of ADHD diagnosis and nonmedical prescription stimulant use in medical students. Acad Psychiatry 2010;34:220-3. doi: 10.1176/appi.ap.34.3.220

36. Webb JR, Valasek MA, North CS. Prevalence of stimulant use in a sample of US medical students. Ann Clin Psychiatry 2013;25:27-32. PMID: 23376867

37. Graff Low K, Gendaszek AE. Illicit use of psychostimulants among college students: A preliminary study. Psychol Health Med 2002;7:283-7. doi: 10.1080/13548500220139386

38. Barrett SP, Darredeau C, Bordy LE, Pihl RO. Characteristics of methylphenidate misuse in a university student sample. Can J Psychiatry 2005;50:457-61. doi : 10.1177/070674370505000805

39. Teter CJ, McCabe SE, LaGrange K, Cranford JA, Boyd CJ. Illicit use of specific prescription stimulants among college students: prevalence, motives, and routes of administration. Pharmacotherapy 2006;26:1501-10. doi: 10.1592/ phco.26.10.1501

40. Sattler S, Mehlkop G, Graeff P, Sauer C. Evaluating the drivers of and obstacles to the willingness to use cognitive enhancement drugs: the influence of drug characteristics, social environment, and personal characteristics. Subst Abuse Treat Prev Policy 2014;9:8. doi: 10.1186/1747-597X-9-8

41. Ilieva IP, Hook CJ, Farah MJ. Prescription stimulants' effects on healthy inhibitory control, working memory, and episodic memory: a meta-analysis. J Cogn Neurosci 2015;27:1069-89. doi: 10.1162/jocn_a_00776
42. Smith ME, Farah MJ. Are prescription stimulants "smart pills"? The epidemiology and cognitive neuroscience of prescription stimulant use by normal healthy individuals. Psychol Bull 2011;137:717-41. doi: 10.1037/a0023825

43. McGaugh JL, Roozendaal B. Drug enhancement of memory consolidation: historical perspective and neurobiological implications. Psychopharmacology (Berl) 2009;202:3-14. doi: 10.1007/s00213-008-1285-6

44. Soetens E, Casaer S, D'Hooge R, Hueting JE. Effect of amphetamine on long-term retention of verbal material. Psychopharmacology (Berl) 1995;119:155-62. doi: 10.1007/ BF02246156

45. Marraccini ME, Weyandt LL, Rossi JS, Gudmundsdottir BG. Neurocognitive enhancement or impairment? A systematic meta-analysis of prescription stimulant effects on processing speed, decision-making, planning, and cognitive perseveration. Exp Clin Psychopharmacol 2016;24:269-84. doi: 10.1037/pha0000079

46. Ilieva IP, Farah MJ. Enhancement stimulants: perceived motivational and cognitive advantages. Front Neurosci 2013;7:198. doi: 10.3389/fnins.2013.00198

47. Vrecko S. Just how cognitive is "Cognitive Enhancement"? On the significance of emotions in university students' experiences with study drugs. AJOB Neurosci 2013;4:4-12. doi: 10.1080/21507740.2012.740141

48. Cropsey KL, Schiavon S, Hendricks PS, Froelich M, Lentowicz I, Fargason R. Mixed-amphetamine salts expectancies among college students: Is stimulant induced cognitive enhancement a placebo effect? Drug Alcohol Depend 2017;178:302-9. doi: 10.1016/j. drugalcdep.2017.05.024

49. Wood S, Sage JR, Shuman T, Anagnostaras SG. Psychostimulants and cognition: a continuum of behavioral and cognitive activation. Pharmacol Rev 2014;66:193-221. doi: $10.1124 /$ pr.112.007054

50. Taylor SF, Welsh RC, Wager TD, Luan Phan K, Fitzgerald $\mathrm{KD}$, Gehring WJ. A functional neuroimaging study of motivation and executive function. Neuroimage 2004;21:1045-54. doi: 10.1016/j.neuroimage.2003.10.032

51. Marshuetz C, Smith EE. Working memory for order information: Multiple cognitive and neural mechanisms. Neuroscience 2006;139:195-200. doi: 10.1016/j. neuroscience.2005.08.024

52. Curtis CE. Prefrontal and parietal contributions to spatial working memory. Neuroscience 2006;139:173-80. doi: 10.1016/j.neuroscience.2005.04.070

53. Nebel K, Wiese H, Stude P, de Greiff A, Diener H-C, Keidel M. On the neural basis of focused and divided attention. Cogn Brain Res 2005;25:760-76. doi: 10.1016/j. cogbrainres.2005.09.011

54. Rowe JB, Owen AM, Johnsrude IS, Passingham RE. Imaging the mental components of a planning task. Neuropsychologia 2001;39:315-27. doi: 10.1016/S0028-3932(00)00109-3

55. Yerkes RM, Dodson JD. The relation of strength of stimulus to rapidity of habit-formation. J Comp Neurol Psychol 1908;18:459-82. doi: 10.1002/cne.920180503.

56. Yerkes RM. Modifiability of behavior in its relations to the age and sex of the dancing mouse. J Comp Neurol Psychol 1909;19:237-71. doi: 10.1002/cne.920190303

57. Dodson JD. The relation of strength of stimulus to rapidity of habit-formation in the kitten. J Anim Behav 1915;5:330-6. doi: $10.1037 / \mathrm{h} 0073415$ 
58. Chaby LE, Sheriff MJ, Hirrlinger AM, Braithwaite VA. Can we understand how developmental stress enhances performance under future threat with the Yerkes-Dodson law? Commun Integr Biol 2015;8:e1029689. doi: 10.1080/19420889.2015.1029689

59. Broadhurst PL. Emotionality and the Yerkes-Dodson law. J Exp Psychol 1957;54:345-52. doi: 10.1037/h0049114

60. Salehi B, Cordero MI, Sandi C. Learning under stress: the inverted-U-shape function revisited. Learn Mem 2010;17:52230. doi: $10.1101 / \mathrm{lm} .1914110$

61. Diamond DM, Campbell AM, Park CR, Halonen J, Zoladz PR. The temporal dynamics model of emotional memory processing: a synthesis on the neurobiological basis of stressinduced amnesia, flashbulb and traumatic memories, and the Yerkes-Dodson law. Neural Plast 2007;2007:60803. doi: $10.1155 / 2007 / 60803$

62. Pribram KH, McGuinness D. Arousal, activation, and effort in the control of attention. Psychol Rev 1975;82:116-49. doi: 10.1037/h0076780

63. Lafreniere KD. Reversal theory: an introduction. Patient Educ Couns 1993;22:63-71. doi: 10.1016/0738-3991(93)90002-E

64. Martin RA, Kuiper NA, Olinger LJ, Dobbin J. Is stress always bad? Telic versus paratelic dominance as a stress-moderating variable. J Pers Soc Psychol 1987;53:970-82. doi: 10.1037/0022-3514.53.5.970

65. Kuczenski R, Segal DS. Effects of methylphenidate on extracellular dopamine, serotonin, and norepinephrine: comparison with amphetamine. J Neurochem 1997;68:20327. doi: 10.1046/j.1471-4159.1997.68052032.x

66. Berridge CW, Devilbiss DM, Andrzejewski ME, Arnsten AFT, Kelley AE, Schmeichel B, Hamilton C, Spencer RC. Methylphenidate preferentially increases catecholamine neurotransmission within the prefrontal cortex at low doses that enhance cognitive function. Biol Psychiatry 2006;60:1111-20. doi: 10.1016/j.biopsych.2006.04.022

67. Schmeichel BE, Berridge CW. Neurocircuitry underlying the preferential sensitivity of prefrontal catecholamines to lowdose psychostimulants. Neuropsychopharmacology 2013;38:1078-84. doi: 10.1038/npp.2013.6

68. Wood SC, Anagnostaras SG. Memory and psychostimulants: modulation of Pavlovian fear conditioning by amphetamine in C57BL/6 mice. Psychopharmacology (Berl) 2009;202:197206. doi: 10.1007/s00213-008-1185-9

69. Madras BK, Xie Z, Lin Z, Jassen A, Panas H, Lynch L, Johnson R, Livni E, Spencer TJ, Bonab AA, Miller GM, Fischman AJ. Modafinil occupies dopamine and norepinephrine transporters in vivo and modulates the transporters and trace amine activity in vitro. J Pharmacol Exp Ther 2006;319:561-9. doi: 10.1124/jpet.106.106583

70. Ferraro L, Fuxe K, Tanganelli S, Fernandez M, Rambert FA, Antonelli T. Amplification of cortical serotonin release: a further neurochemical action of the vigilance-promoting drug modafinil. Neuropharmacology 2000;39:1974-83. doi: 10.1016/s0028-3908(00)00019-8

71. Huang Q, Zhang L, Tang H, Wang L, Wang Y. Modafinil modulates GABA-activated currents in rat hippocampal pyramidal neurons. Brain Res 2008;1208:74-8. doi: 10.1016/j.brainres.2008.02.024

72. Haris M, Singh A, Cai K, Nath K, Verma G, Nanga RPR, Hariharan H, Detre JA, Epperson N, Reddy R. High resolution mapping of modafinil induced changes in glutamate level in rat brain. PLoS One 2014;9:e103154. doi: 10.1371/journal.pone.0103154

73. Ishizuka T, Murotani T, Yamatodani A. Modanifil activates the histaminergic system through the orexinergic neurons. Neurosci Lett 2010;483:193-6. doi: 10.1016/j. neulet.2010.08.005

74. Mereu M, Chun LE, Prisinzano T, Newman AH, Katz JL, Tanda G. The unique psychostimulant profile of $( \pm)$-modafinil: investigation of behavioral and neurochemical effects in mice. Eur J Neurosci 2017; 45:167-74. doi: 10.1111/ejn.13376

75. Repantis D, Maier LJ, Heuser I. Correspondence arising: Modafinil for cognitive neuroenhancement in health nonsleep-deprived-subjects. Eur Neuropsychopharmacol 2016;26:392-3. doi: 10.1016/j.euroneuro.2015.12.016

76. Wesensten NJ, Belenky G, Kautz MA, Thorne DR, Reichardt RM, Balkin TJ. Maintaining alertness and performance during sleep deprivation: modafinil versus caffeine. Psychopharmacology (Berl) 2002;159:238-47. doi: 10.1007/ s002130100916

77. Wesensten NJ, Killgore WDS, Balkin TJ. Performance and alertness effects of caffeine, dextroamphetamine, and modafinil during sleep deprivation. J Sleep Res 2005; 14:25566. doi: 10.1111/j.1365-2869.2005.00468.x

78. Franke AG, Gränsmark P, Agricola A, Schühle K, Rommel T, Sebastian A, Balló HE, Gorbulev S, Gerdes C, Frank B, Ruckes C, Tüscher O, Lieb K. Methylphenidate, modafinil, and caffeine for cognitive enhancement in chess: A doubleblind, randomised controlled trial. Eur Neuropsychopharmacol 2017;27:248-60. doi: 10.1016/j.euroneuro.2017.01.006

79. Myrick H, Malcolm R, Taylor B, LaRowe S. Modafinil: preclinical, clinical, and post-marketing surveillance - a review of abuse liability issues. Ann Clin Psychiatry 2004;16:101-9. doi: 10.1080/10401230490453743

80. Malcolm R, Book SW, Moak D, DeVane L, Czepowicz V. Clinical applications of modafinil in stimulant abusers: low abuse potential. Am J Addict 2002;11:247-9. doi: 10.1080/10550490290088027

81. Warot D, Corruble E, Payan C, Weil JS, Puech AJ. Subjective effects of modafinil, a new central adrenergic stimulant in healthy volunteers: a comparison with amphetamine, caffeine and placebo. Eur Psychiatry 1993;8:201-8.

82. Cope ZA, Minassian A, Kreitner D, MacQueen DA, Milienne-Petiot M, Geyer MA, Perry W, Young JW. Modafinil improves attentional performance in healthy, nonsleep deprived humans at doses not inducing hyperarousal across species. Neuropharmacology 2017;125:254-62. doi: 10.1016/j.neuropharm.2017.07.031

83. Ozturk A, Deveci E. Drug abuse of modafinil by a cannabis user. Klin Psikofarmakol Bülteni - Bulletin Clin Psychopharmacol 2014;24:405-7. doi: 10.5455/ bcp.20130624013303

84. Krishnan R, Chary KV. A rare case modafinil dependence. J Pharmacol Pharmacother 2015;6:49-50. doi: 10.4103/0976500X.149149

85. Schmidt A, Müller F, Dolder PC, Schmid Y, Zanchi D, Egloff L, Liechti ME, Borgwardt S. Acute effects of methylphenidate, modafinil, and MDMA on negative emotion processing. Int J Neuropsychopharmacol 2018;21:345-54. doi: 10.1093/ijnp/ pyx 112

86. Kampman KM, Lynch KG, Pettinati HM, Spratt K, Wierzbicki MR, Dackis C, O'Brien CP. A double blind, placebo controlled trial of modafinil for the treatment of 
cocaine dependence without co-morbid alcohol dependence. Drug Alcohol Depend 2015;155:105-10. doi: 10.1016/j. drugalcdep.2015.08.005

87. Mahoney JJ, Jackson BJ, Kalechstein AD, De La Garza R, Chang LC, Newton TF. Acute modafinil exposure reduces daytime sleepiness in abstinent methamphetamine-dependent volunteers. Int J Neuropsychopharmacol 2012;15:1241-9. doi: $10.1017 / \mathrm{S} 1461145711001805$

88. Ghahremani DG, Tabibnia G, Monterosso J, Hellemann G, Poldrack RA, London ED. Effect of modafinil on learning and task-related brain activity in methamphetamine- dependent and healthy individuals. Neuropsychopharmacology 2011;36:950-9. doi: 10.1038/npp.2010.233

89. Hatori M, Gronfier C, Van Gelder RN, Bernstein PS, Carreras J, Panda S, Marks F, Sliney D, Hunt CE, Hirota T, Furukawa T, Tsubota K. Global rise of potential health hazards caused by blue light-induced circadian disruption in modern aging societies. NPJ Aging Mech Dis 2017;3:9. doi: 10.1038/ s41514-017-0010-2

90. Medic G, Wille M, Hemels ME. Short- and long-term health consequences of sleep disruption. Nat Sci Sleep 2017;9:15161. doi: $10.2147 /$ NSS.S134864

\section{U potrazi za optimalnom psihoaktivacijom - stimulansi kao pojačivači kognitivne funkcije}

Sve više ljudi, napose studenata, traži tvari kojima će poboljšati svoju kognitivnu funkciju. Najpopularniji među farmakološkim pojačivačima kognitivne funkcije jesu stimulansi. Rezultati dostupnih istraživanja pokazuju blago, povoljno djelovanje metilfenidata i amfetamina na pamćenje, izvršne funkcije i brzinu obrade (procesiranja). Premda je poboljšanje blago, ono u studenata može značiti razliku između uspjeha i neuspjeha. Posljednjih se je godina istraživanje usmjerilo na dodatne povoljne učinke stimulansa na emocionalno stanje, povećanu motivaciju, pa i na kognitivna poboljšanja povezana s placebom. U ovom se radu daje kratki pregled najnovijih i najvažnijih istraživanja odnosa između popularnih stimulansa i poboljšanja kognitivne funkcije. Taj se odnos ne može razumjeti bez poznavanja Yerkes-Dodsonova zakona, koji objašnjava odnos između razine uzbuđenosti i izvedbe (performanse) te govori o tome da stimulansi djeluju u kontinuumu koji je ovisan o dozi. Zakon je opetovano potvrđivan istraživanjima u kojima je optimalna razina psihoaktivacije za poboljšanje kognitivne funkcije postignuta niskim dozama stimulansa, a previsoke razine dovodile su do pada kognitivnih deficita, psihomotorne agitacije i ovisnosti. Dio je teksta posvećen modafinilu, sve popularnijem stimulansu koji se svojim neurokemijskim svojstvima i djelovanjem na ponašanje razlikuje od ostalih.

KLJUČNE RIJEČI: amfetamin, metilfenidat, modafinil, stimulansi središnjega živčanoga sustava 